\title{
JOLANTA SAWICKA
}

(Warszawa)

\section{OSOBLIWOŚĆ EMPIRYCZNA DOŚWIADCZENIA RELIGIJNEGO. WILLIAM JAMES I DUCHOWY PRAGMATYZM}

William James w historii filozofii zapisał się przede wszystkim pod takimi hasłami, jak pragmatyzm, pragmatyczna teoria prawdy czy radykalny empiryzm. $\mathrm{W}$ pierwszej chwili, kiedy radykalny empirysta zajmuje się zagadnieniami związanymi z religią, co więcej, zagadnieniem indywidualnego doświadczenia religijnego, wówczas pojawia się intelektualne poczucie niezgodności. Zestawienie takie, czyli połączenie doświadczenia ze zjawiskiem religii, wydaje się być swego rodzaju sprzecznością lub błędem poznawczym. Jak można mówić o doświadczeniu, $\mathrm{w}$ przypadku religii, której istota tkwi w wielkiej tajemnicy wiary, niedostępnej zmysłom i rozumowi. Jednak wraz z głębszą refleksja nad myślą Jamesa wyraźnie widać nieprzypadkowy związek między jego pragmatyzmem, empiryzmem, a sposobem ujmowania doświadczenia religijnego. Kluczem do powiązania tych terminów (pragmatyzm, empiryzm, religia), jest pojęcie doświadczenia, a dokładnie, osobliwe rozumienie doświadczenia przez Jamesa.

Badanie religii, której źródłem jest tradycja, nie znajduje się w centrum zainteresowania Jamesa, ponieważ w jego opinii jest ona wtórna ${ }^{1}$. Religia taka jest efektem zasugerowanych uczuć i naśladowanych postaw ${ }^{2}$. James natomiast po-

\footnotetext{
1 Dzieło Williama Jamesa Odmiany doświadczenia religijnego jest efektem cyklu wykładów, które filozof wygłosił w latach 1901-1902 na uniwersytecie w Edynburgu. Przedmiotem jego analizy były podstawy życia religijnego oraz jego znaczenie dla jednostkowej świadomości ludzkiej.

2 Całkowicie odmienne zdanie prezentuje Gerardus van der Leeuw, dla którego błędem jest przeciwstawianie religii „instytucjonalnej” wewnętrznemu przeżyciu religijnemu. Co więcej, subiektywne doświadczenie nie należy przeciwstawiać doświadczeniu zbiorowemu: „(..) w pewnym sensie wszystko jest $\mathrm{w}$ religii osobiste, o tyle mianowicie, o ile nigdy nie może się tu nic przejawić poza obrębem aktualnej sytuacji, poza egzystencjalną określonością człowieka; ale zobaczymy
} 
szukuje oryginalnych doświadczeń, które poprzedzałby wyznanie instytucjonalnie zorganizowane. Już na samym wstępie swoich rozważań zaznacza, że jeżeli jego dociekania mają dotyczyć psychologii religii, to przedmiotem owych badań nie mogą być instytucje religijne, ale bezpośrednie uczucia i przeżycia związane z wiarą. Sama religia jest zjawiskiem złożonym, na co wskazuje różnorodność odnoszących się do niej określeń. Jest nazwą zbiorową, której istotę trudno określić jakimś jednym konkretnym mianem. Źródłem religii może być uczucie zależności, strach, poczucie nieskończoności, uległość etc. James, aby usprawnić poszukiwanie osobliwości doświadczenia religijnego, dokonuje ograniczenia przedmiotu badań i wprowadza dystynkcję na religię instytucjonalną i religię osobistą (pierwotną). Przy czym całkowicie pomija pierwszą (gałąź instytucjonalną); jak sam wyraźnie podkreśla: „Nie powiem nic o organizacji kościelnej, możliwie najmniej o teologii systematycznej i o pojęciach odnoszących się do samych bogów, ograniczę się za to w miarę możności do czystej i prostej religii osobistej" ${ }^{3}$. Religia osobista jest logicznie i faktycznie wcześniejsza od religii zinstytucjonalizowanej, ponieważ opiera się na doświadczeniu, które James pojmuje w sposób szczególny, o czym będzie mowa w dalszej części pracy. Zatem religia w przyjętym przez Jamesa znaczeniu oznacza „takie uczucia, czyny i doświadczenia odosobnionej jednostki ludzkiej, o których sądzi ona, że odnoszą się do czegoś, co sama uznaje za boskie" ${ }^{4}$. Przy czym termin «boskie» pojmować należy szeroko, niezależnie od tego, czy to, co terminowi odpowiada, jest czy nie jest bogiem upostaciowionym. Cechy boskości przysługują rzeczom najpierwotniejszym, wszechobejmującym i najgłębiej prawdziwym (rzeczywistym przeżyciowo).

Religia pierwotna (osobista) nastręcza zdecydowanie większą problematyczność, ponieważ według Jamesa religia zaczyna się od doświadczenia jednostkowego i zasadniczo zawsze pozostaje w jego obrębie ${ }^{5}$. Natomiast religia zinstytucjonalizowana konstruowana jest w oparciu o dyskurs, interpretację, co w jakiejś mierze napełniało Jamesa nieufnością wobec niej. Uważał bowiem, że łatwo ulega zniekształceniom i zepsuciu. „Bardzo często na religię spada zarzut pospolitości stwierdza James - zwykle jednak należałoby go stawiać nie tyle samej religii,

też, że nie ma tu niczego czysto osobistego, jako że nic nie mogłoby się przejawić, gdyby nie zostało uprzednio zrozumiane przez jakiegoś innego człowieka". G. van der Leeuw, Fenomenologia religii, przeł. Jerzy Prokopiuk, Warszawa 1997, s. 399. Doświadczenie wewnętrzne zatem nie tylko należy rozpatrywać od strony wrażenia, lecz także od strony wyrazu.

3 W. James, Odmiany doświadczenia religijnego. Studium ludzkiej natury, przeł. Jan Hempel, Warszawa 2011, s. 37.

4 Tamże, s. 38.

5 James utożsamiał religię z jednostkowymi procesami psychicznymi. W ogóle wszystkie jego badania w punkcie wyjścia skupione były wokół badań konkretnych jednostek; nie traktował kolektywnie materiału empirycznego, lecz zawsze podkreślał wagę indywidualnych przypadków. 
ile raczej jej praktycznemu sąsiadowi - duchowi władzy korporacyjnej. Podobnie za bigoterię nie należy winić religii, lecz jej intelektualnego sąsiada - ducha władzy dogmatycznej, gwałtowną potrzebę wyrażenia prawa w formie absolutnie zamkniętego systemu teoretycznego. Duch eklezjastyczny w ogóle jest sumą tych dwóch duchów władzy. Nie należy też zjawisk należących wyłącznie do psychologii plemiennej i korporacyjnej mieszać z przejawami czystego życia duchowego, które są wyłączonym przedmiotem naszych badań" ${ }^{6}$.

Indywidualne doświadczenie jest głównym materiałem badawczym Jamesa. Warto jednak podkreślić, że doświadczenie to musi być jaskrawe i mocne, pochodzące od osób o najpełniejszym życiu religijnym, posiadających równocześnie umiejętność zrozumiałego wypowiedzenia poglądów, wrażeń, pobudek, których doświadczają w ramach religijnego uniesienia. Doświadczenie oryginalne nie przypada w udziale zwykłym jednostkom, przestrzegającym obrządków w ramach danej religii. Takie doświadczenia przypadają w udziale „geniuszom" religijnym, dla których religia nie jest zwyczajem obojętnym, lecz przejawia się w formie nieustającego pobudzenia. „Geniusze religijni, jak ludzie genialni w innych dziedzinach - pisze James - nieraz ujawniali oznaki niezrównoważenia nerwowego. Być może ludzie wybitni w dziedzinie religijnej podlegali nawiedzeniom psychopatycznym nawet częściej niż inne rodzaje geniuszy. Zawsze były to jednostki o przeczulonej pobudliwości wzruszeniowej. Ich życie wewnętrzne często było burzliwe i w pewnym swym okresie podległe melancholii. Ludzie ci nie znali miary, ulegali przywidzeniom i natrętnym wyobrażeniom, często wpadali w trans, słyszeli głosy, miewali widzenia i wykazywali różnego rodzaju osobliwości zwykle uznawane za chorobliwe" 7 . Z tej też przyczyny nietrudno jest zdyskredytować stany duchowe za pomocą odwołań do źle funkcjonującego organizmu albo, co zdaniem Jamesa jest bardziej wulgarną formą zakwestionowania uczucia religijnego, przez uwypuklanie ich związku z życiem płciowym, niespełnionymi instynktami czy niezrealizowanymi potrzebami.

Stany duchowe przez naukowców traktowane są przede wszystkim jako zaburzenia umysłowe. James jednak zauważa, że zgodnie z ogólnym poglądem psychologicznym nie ma stanu duchowego, wyższego lub niższego, zdrowego lub chorobliwego, który nie byłby uwarunkowany przez jakiś stan fizyczny, nie wywoływałby jakiegoś napięcia w umyśle, czy chwilowych zmian w organizmie ${ }^{8}$. Wszystko

\footnotetext{
6 W. James, Odmiany doświadczenia religijnego..., wyd. cyt., s. 310.

7 Tamże, s. 18-19.

8 „Teorie naukowe - podkreśla James - są tak samo uwarunkowane ustrojowo jak wzruszenia religijne i jeśli tylko moglibyśmy dostatecznie poznać fakty, niewątpliwie przekonalibyśmy się, że «wątroba» w równym stopniu wpływa na opinie najbardziej zatwardziałego ateisty, jak na zaniepokojonego o swą duszę metodysty. Gdy ta wątroba przemieni przepływającą przez nią krew
} 
jest w pewnym stopniu ustrojowo uwarunkowane: zachwyt, pożądanie, wzruszenie, wiara, zwątpienie. Nie ma tu znaczenia, czy treść ich jest religijna, czy niereligijna ${ }^{9}$. Zatem krytykowanie lub zmniejszanie wartości stanów duchowych poprzez odwołanie się do funkcjonowania organizmu jest czymś arbitralnym. Widać wyraźnie, że autor Odmian doświadczenia religijnego polemizuje z materializmem lekarskim, który jego zdaniem przybiera postać dogmatyzmu i odrzuca zjawiska religijne ze względu na ich genezę (natchnienie wewnętrzne, objawienie nadprzyrodzone). James natomiast chce, rozpoczynajacc od pragmatycznego i empirycznego stanowiska filozoficznego, pokazać nowy sposób rozważenia kwestii religii. W tym też celu kryterium empiryczne Jamesa nie polega na odszukaniu poparcia jakiegoś wierzenia na zasadzie jego pochodzenia, lecz na sposobie jego działania w ogóle ${ }^{10}$.

Warto jeszcze raz w tym miejscu podkreślić, że wszelkie wprowadzone przez Jamesa dystynkcje czy ograniczenia przedmiotu badań mają służyć odnalezieniu niepowtarzalności i osobliwości doświadczenia religijnego, takiego elementu, który nie byłby redukowalny do żadnego innego; takiego pierwiastka lub takiej właściwości, której nie spotka się nigdzie poza tym doświadczeniem. Z tej też przyczyny James zajmuje się przypadkami w postaci skrajnie wyolbrzymionej i najwydatniejszej. Uwaga autora skupia się na takich doświadczeniach, w których uczucia religijne występują bezspornie, jaskrawo i najintensywniej ${ }^{11}$.

Samo doświadczenie, a raczej sposób, w jaki definiował je James, jest kluczowe dla zrozumienia sensu tych badań. Kiedy po raz pierwszy natrafiamy na połaczzenie doświadczenia z wiarą, czy szerzej, z religią, to „zestawienie” takie wydaje się być co najmniej sprzecznością lub błędem epistemologicznym. Jak bowiem realnie można doświadczyć czegoś, jak w ogóle można mówić o doświadczeniu, w przypadku religii, której istota polega nie na wiedzy, zmysłowym poznawaniu, lecz na wierze. Co zatem skłoniło Jamesa, który w historii filozofii funkcjonuje jako

w jednym kierunku, otrzymujemy metodystę, gdy w drugim - ateistę". W. James, Odmiany doświadczenia religijnego..., wyd. cyt., s. 25. Dziś już wiemy, że dysponujemy także tzw. genem Boga, biologicznym mechanizmem odpowiedzialnym za ,istnienie” w naszym mózgu uczuć religijnych, za nasze życie duchowe. Jednak czy wyklucza to autentyczność wiary? Wiedza na temat związków chemicznych wywołujących stan zakochania nie powoduje, że się nie zakochujemy albo kochamy mniej, nie dyskredytuje to autentyczności naszych emocji w relacji do drugiej osoby.

9 Jedność psychiki i fizjologii była dla Jamesa potwierdzona przez doświadczenia.

10 Zob. W. James, Z wybranych problemów filozofii, przeł. Michał Filipczuk, Kraków 2004, s. $113-119$.

11 James w tym celu posługuje się metodą zaczerpniętą z praktyk naukowych: „W fizjologii przyjęto za dobrą zasadę, że badając działanie i użytek danego narządu, staramy się poznać go w jakiejś najbardziej znamiennej dlań czynności i w miarę możności poszukujemy takich jego działań, których żaden inny narząd nie potrafi wykonać. Zasada ta może nam się tu bardzo przydać. Istotą doświadczenia religijnego, tym, na podstawie czego ostatecznie osądzamy je, musi być taki pierwiastek lub taka właściwość, których nie poznamy nigdzie poza tym doświadczeniem". W. James, Odmiany doświadczenia religijnego..., wyd. cyt., s. 50. 
radykalny empirysta i współtwórca pragmatyzmu (dziedzin nie przystających do zagadnień związanych z jakimikolwiek religijnymi wierzeniami) do podjęcia analizy doświadczenia religijnego i poszukiwania tego doświadczenia osobliwości?

Rzeczą oczywistą jest, że w pierwszej kolejności należy wymienić ogólne zainteresowania Jamesa. Obok filozofii studiował chemię, biologię i ukończył medycynę. Następnie zajął się psychologią, co zaowocowało dziełem The Principles of Psychology (1890), które w efekcie przyniosło mu światową renomę. Zatem z jednej strony zajmował się wiedzą empiryczną, z drugiej zaś uprawiał problematykę antropologiczną. Korelował ze sobą dwa kierunki: psychologię i filozofię, co w jego myśli przejawiało się pod postacią pluralizmu ontologicznego (wielość indywidualnych światów, doświadczenie relatywizowane do ja). Wystawiony był przez to na krytykę w dwójnasób - filozofowie zarzucali mu, że psychologizował, a psychologowie, że za bardzo skupiał się na elementach filozoficznych ${ }^{12}$. Faktem natomiast jest, że dzięki swej działalności i oryginalności, wynikającej z szerokiego spektrum jego zainteresowań, przyczynił się do rozpowszechnienia filozofii w Stanach Zjednoczonych.

Powracając do rozważań Jamesa o doświadczeniu, autor Pragmatyzmu rozumiał je nie tylko jako rezultat odbioru bodźców, jako zbiór partykularnych zdarzeń, lecz jako ciągłość, jako strumień przeżyć ${ }^{13}$; wszystko się łączy i przenika, poznanie zmysłowe z intelektualnym. Ma własny czas i jest zależny wyłącznie od jednostkowego $\mathrm{ja}^{14}$. Filozofia Jamesa stoi w opozycji do dualizmu psychofizycznego Descartesa. Co więcej, doświadczenie czegoś jest wynikiem działania także jednostkowej woli. Wola jest rudymentarną formą aktywności podmiotowej. Formuje, nadaje kierunek i kształt wielości przeżyć. Wola ma charakter personalny. Kształtuje odmienne potoki świadomości, nie jest zdeterminowana. W woli

12 Zob. S. Blackburn, William James, w: Oksfordzki slownik filozoficzny, przeł. Michał Szczubiałka, red. naukowa Jan Woleński, Warszawa 2004, s. 178.

13 Jamesowska koncepcja potoku świadomości inspirująco wpłynęła na Bergsona i Husserla, którzy sami wielokrotnie się do tego przyznawali i podkreślali swoją wdzięczność wobec nowojorskiego filozofa. Nie obyło się jednak bez zarzutów o plagiat. Głównie obiekcje dotyczyły Bergsona, którego oskarżono o oparcie idei rzeczywistego trwania na teorii strumienia świadomości Williama Jamesa. Bergson zaprzeczały temu, jednakowoż uznawał podobieństwa zachodzące między jego myślą a Jamesa. Zob. F. Copleston, Historia filozofi, t. IX, przeł. Bohdan Chwedeńczuk, Warszawa 1991, s. 213-214.

14 Niezwykle interesującym w tym kontekście i rozjaśniającym pojęcie doświadczenia jest esej Barbary Skargi Doświadczenie. Skarga pisze o doświadczeniu źródłowym i zestawia je z świadomością i świadectwem. Nie wystarczy doświadczyć, trzeba jeszcze mieć tego doświadczenia wyraźną świadomość i móc o tym zaświadczyć: „Doświadczenie ma o czymś świadczyć - pisze Skarga - a ten kto doświadcza, jest po prostu świadkiem. Jest się więc świadkiem czegoś, czyli mamy tu do czynienia z konstrukcją intencjonalną, Ja jestem wobec czegoś, i co więcej jestem tego czegoś świadomy, inaczej nie mógłbym świadczyć". B. Skarga, Doświadczenie, w: Kwintet metafizyczny, Kraków 2005. Z tego by wynikało, że doświadczenie religijne rzeczywiście jest doświadczeniem czegoś Nieskończonego, Boskiego, Absolutnego, to znaczy, jest swego rodzaju dowodem, świadectwem istnienia Absolutu, Innej Rzeczywistości. 
wyrażają się nasze uczucia, potrzeby, dążenia. Stąd też wniosek Jamesa, że tak poznanie, jak i doświadczenie nie są bezinteresowne, zawsze czemuś służą, zawsze mają wymiar pragmatyczny.

Gdy nachodzi nas poczucie marności i znikomości wszystkiego, co wysiłkiem woli tworzymy w życiu, wówczas przychodzi z pomocą religia. Ludzie religijni wchodzą w taki stan umysłu, w którym silniejsza niż strach przed niepewnym czy tajemniczym jest wola samopotwierdzenia. Odchodzi wtedy w cień niepewność i napięcie wewnętrzne, a w miejsce troski o przyszłość pojawia się szczęśliwe rozluźnienie i „spokojny oddech teraźniejszości wiekuistej” ${ }^{15}$. Taki stan umysłu jest szczęśliwym stanem, którego podobnie jak miłość, gniew, ambicje, zazdrość nie sposób wyprowadzić racjonalnie lub logicznie z niczego innego. Stan ten przychodzi, jak pisze James, w postaci «daru». Jedni go otrzymują, a inni nie. W tym też sensie, uczucie religijne jest dodatkiem do poziomu życia jednostki. James to uczucie osób głęboko, wręcz mistycznie wierzących określa nową siłą: „Gdy zewnętrzną bitwę przegrano, gdy świat zewnętrzny wyrzekł się człowieka, uczucie religijne zbawia i ożywia świat wewnętrzny, który w przeciwnym razie byłby pustą stratą" 16 .

Jednak Jamesowi nie chodzi o proste utożsamienie religii z formą szczęśliwości. Uczucie religijne, jak wynika z jego badań, nie jest tylko i wyłącznie przejawem ucieczki lub nieustannego unikania czegoś, chociaż w przypadku niektórych ludzi tak to właśnie wygląda. Siła religijnej szczęśliwości polega na zgodzeniu się z istnieniem zła, wiedząc jednocześnie, że zło jest już pokonane na zawsze. Element negatywny lub tragiczny wzbogaca świadomość religijną. Wprowadza skłonność do poświęcania się, przybiera również postać ekstremalnie ascetyczną ${ }^{17}$. Jednak forma religijności przede wszystkim zależy od temperamentu konkretnej jednostki.

Z opinii Jamesa wynika, że religia, uczucia religijne posiadają ogromną moc odwracania znaczenia i wpływania na zachowanie człowieka, jak gdyby wbrew jego naturze. Człowiek bez «daru» religijności, czuje się całkowicie zależny od świata, zmuszony do przyjmowania poświęceń i cierpień jako konieczności. Natomiast w życiu religijnym jest zupełnie odwrotnie. Cierpienie i poświęcenie wyczekiwane jest z utęsknieniem, a przyjmowane jest z otwartymi rękami. Religia czyni łatwym i prostym to, co jest nieuniknione.

15 W. James, Odmiany doświadczenia religijnego..., wyd. cyt., s. 52.

16 Tamże, s. 52-53.

17 „Są święci, którzy dosłownie żywili się negacją - pisze James - żywili się upokorzeniem, niedostatkiem i myślą o cierpieniu i śmierci; dusze ich były tym szczęśliwsze, im bardziej nie do zniesienia stawał się stan zewnętrzny. Żadne inne wzruszenie oprócz religijnego nie mogłoby doprowadzić człowieka do czegoś tak dziwnego. I dlatego sądzę, że gdy stawimy pytanie o wartości religii dla życia ludzkiego, to odpowiedzi szukać musimy raczej wśród poruszających niż wśród bardziej umiarkowanych przykładów". W. James, Odmiany doświadczenia religijnego..., wyd. cyt., s. 54-55. 
Religijną postawę ducha można ogólnie określić jako wiarę w porządek wyższy i niewidzialny, od którego zależy najwyższe nasze dobro. James charakteryzując w ten sposób życie religijne, chce zwrócić uwagę na niektóre właściwości psychiki wpływające na wiarę w przedmiot niewidzialny. „Wszystkie nasze postawy moralne - stwierdza James - praktyczne i uczuciowe, a także religijne zawdzięczamy «przedmiotom» naszej świadomości, czyli rzeczom, o których sądzimy, że - realnie lub idealnie - istnieją wespół z nami. Przedmioty te mogą istnieć dla nas zmysłowo lub umysłowo, w każdym razie doprowadzają nas do reakcji" 18.

Większość ludzi jednak swoje przedmioty religijnego czczenia zna wyłącznie jako idee ${ }^{19}$. Jeżeli wiara $\mathrm{w}$ istoty boskie stanowi zasadniczy element postawy religijnej, to odbywa się to przede wszystkim za pośrednictwem czystych idei, czyli takich, które nie mają bezpośredniego wzorca w doświadczeniu jednostki. „Bóg”, „dusza”, „nieśmiertelność” - nie mają odpowiadającej im treści zmysłowej, zatem z teoretycznego punktu widzenia, pozbawione są sensu. Mają jednak znaczenie dla życia praktycznego. Wierzymy, że niewidzialne przedmioty rzeczywiście istnieją i dlatego postępujemy tak, jak gdyby istniał Bóg, dusza, nieśmiertelność ${ }^{20}$.

Umysł wierzy całą swą mocą w rzeczy, których nie jest w stanie nawet pojęciowo uchwycić. Każdą cząstką odczuwa obecność i wielki wpływ sił, o których nie sposób dokładnie orzec, czy te potęgi istnieją ${ }^{21}$. Jednostki będące w głębokim stanie religijnym nie mogą spojrzeć wprost na siły, które tak je pobudzają, ponieważ są bezcielesne i bezkształtne, a jednak za ich pośrednictwem właśnie ujmują wszystkie inne rzeczy. James stwierdza, że możliwość zdeterminowania umysłu przez tego typu abstrakcje należy do istoty natury ludzkiej: „Abstrakcje polaryzują i magnetyzują nas: zwracamy się ku nim lub odwracamy od nich, szukamy ich, dzierżymy je, nienawidzimy ich lub błogosławimy je akurat tak samo, jakby to były konkretne rzeczy. I są to rzeczy, rzeczy w zamieszkiwanym przez nie obszarze nie mniej rzeczywiste niż zmienne rzeczy zmysłowe w przestrzeni" ${ }^{22}$.

Wiele różnych i licznych świadectw, na których James zbudował swoją analizę, prowadzi do wniosku, że jednostka doświadczająca religijnie, jej świadomość, miała lub ma poczucie rzeczywistości innej, obiektywnej, jakby postrzegała „coś”

18 W. James, Odmiany doświadczenia religijnego..., wyd. cyt., s. 57.

19 Tylko nielicznym udało się zmysłowo oglądać Zbawiciela, jak zauważa James. Zapewne ma tu na myśli dwunastu Apostołów.

20 James wprost odwołuje się w tym kontekście do refleksji Kanta nad wiarą w Boga, celem stworzenia, duszą, jej wolnością i nieśmiertelnością oraz przemyśleń filozofa z Królewca nad znaczeniem tych pojęć dla życia moralnego. Zob. W. James, Odmiany doświadczenia religijnego..., wyd. cyt., s. 58-60.

21 Por. R. Otto, Świętość. Elementy irracjonalne w pojęciu bóstwa i ich stosunek do elementów racjonalnych, przeł. Bogdan Kupis, Thesaurus Press 1993, s. 35-38.

22 W. James, Odmiany doświadczenia religijnego..., wyd. cyt., s. 60. Antropomorfizacja jest chyba jedną z najstarszych sposobów ujmowania sił czy to przyrody, czy też bóstwa. 
bardziej ogólnego i głębszego niż wszelkie szczegółowe odczucia. Sposób, w jaki jednostka zinterpretuje świadomość obecności tego „czegoś” bardziej ogólnego i głębszego, zależy, co podkreśla autor, od jej wcześniejszych doświadczeń. Skąd doświadczający wiedzą, że właśnie obecność Boga przypadła im w udziale? Jest to w głównej mierze dyktowane wcześniejszą indoktrynacją religijną. Ważniejszym jednak jest fakt, że wielu ludzi w dziedzinie wyraźnych doświadczeń religijnych za przedmiot swej wiary ma rzeczywistość ujmowaną bezpośrednio prawie zmysłowo, ale nie jako pojęcia uznane przy umysł za prawdziwe na podstawie empirycznego ekwiwalentu. James zaznacza tym samym, że w dziedzinie religijnej faktem jest, iż pierwszeństwo mają czynności podświadome i nieracjonalne. Zatem jeśli ktoś odczuwa obecność Boga żywego, to nawet najsilniejsze dowody, argumenty krytyczne, nie wpłyną i nie zmienią wiary takiego człowieka.

Doświadczenie religijne, forma przejawiania się religijności nie jest jednorodna. Jak sam tytuł książki wskazuje, James zajmuje się odmianami (varietes) doświadczenia religijnego. W jakiejś mierze ich prawdziwością, sposobem przejawiania i tym, w jaki sposób oraz jakie osobliwe elementy takie doświadczenia wprowadzają w życie jednostki.

W pierwszej kolejności analizowana jest «religią osób zdrowomyślnych». Charakteryzuje się ona optymistycznym sposobem myślenia nakierowanym na szczęście jako główny cel ludzkiego życia. Religia takich osób jest każdy trwały entuzjazm ${ }^{23}$. James stwierdza, ze ludzie utożsamiający za pomocą prostej logiki religię ze szczęśliwością są zupełnie niezdolni do zauważenia ciemnych stron życia. Optymizm zwolenników zdrowomyślności stał się niemal chorobliwy. Pisze: „Wydaje się, jakby odcięto im zdolność do choćby przemijającego smutku, do chwili pokory, jakby było to jakieś znieczulenie wrodzone" 24 .

Zdrowomyślność zatem, tak jak przedstawia ją James, jest skłonnością do upatrywania dobra we wszystkich rzeczach ${ }^{25}$. Zdrowomyślność bezwiedna bezpośrednio odczuwa zjawiska, przedmioty, a także różnego rodzaju relacje jako szczęśliwe, natomiast zdrowomyślność metodyczna (świadoma) nadaje im to zna-

23, „...) każde trwałe zadowolenie może wytworzyć pewien rodzaj religii, polegającej na dziękczynnym podziwianiu daru istnienia tak szczęśliwego; musimy także przyznać, że bardziej złożone przeżycia religijne są nowymi sposobami wytwarzania szczęścia, cudownymi drogami wewnętrznymi ku nadprzyrodzonemu rodzajowi szczęścia, odsłaniającemu się wówczas, gdy życie przyrodzone, jak to często bywa, jest nieszczęśliwe". W. James, Odmiany doświadczenia religijnego..., wyd. cyt., s. 79 .

24 Tamże, s. 84.

25 Wydaje się bardzo trafnym i pouczającym przywołanie przez Jamesa typu usposobienia starożytnych Greków, a dokładnie stoików. Dla nich bowiem dobro była dobrem, a zło złem. Wymyślanie zaś drugiego świata jako ucieczki byłoby jedynie kłamstwem a nie ratunkiem. Optymizm zwolenników religii zdrowomyślnych w tym świetle jawi się zbyt sztucznie i nie budzi zaufania. 
czenie na drodze ujmowania abstrakcyjnego; dobro jest istotnym i powszechnym wyglądem bytu, a zło natomiast należy usunąć w cień ${ }^{26}$. „Tam gdzie szczęśliwość rzeczywiście włada - wnioskuje James - tam myśl o złu tak samo nie może nabrać poczucia rzeczywistości jak myśl o dobru tam, gdzie panuje melancholia. Człowiek rzeczywiście szczęśliwy z jakiegoś powodu po prostu nie może uwierzyć w zło" 27.

Obok zdrowomyślności przywołany zostaje także inny religijny prąd zwany „ducholecznictwem” (mind-cure) albo „Nową Myślą", która wyraża optymistyczny schemat życiowy ${ }^{28}$. Oznacza to, że charakterystyczna dla tego ruchu jest intuicyjna wiara w moc odwagi, nadziei, ufności, radości i pogardliwy stosunek wobec zwątpienia, strachu, smutku, życia w nędzy i męczeństwie. Zasada jest prosta, i podobna do tej ze zdrwomomyślności: pesymizm prowadzi do słabości, optymizm natomiast do mocy. Na pytanie, co należy uczynić, aby być zbawionym, odpowiedź brzmi: wystarczy w to uwierzyć, bo już jest się zbawionym.

Potrzeby ludzkie, uczucia i zdolności nieusuwalnie różnią się między sobą. Jest to źródłem także różnych typów doświadczenia religijnego. Uczucia religijne mogą przybrać formę uzdrowienia, zaufania, zjednoczenia w harmonii, braku świadomości czasu, przestrzeni, osób, świadomość miłości, szczęścia i wiary. Te różne formy przemawiają, jak zauważa James, za tezą, że wszechświat jest sprawą dużo bardziej wielostronną, niż wydaje się to niektórym religiom czy sektom. Weryfikacja prawdziwości naszych doświadczeń przebiega według wyodrębnionego lub zbudowanego przez umysł systemu pojęć. Tylko dlaczego należałoby przyjąć za prawdziwy wyłącznie jeden taki system? Dla Jamesa jest oczywiste, że z naszego

26 Jako przykład filozofii odpowiadającej zasadom zdrowomyślności James podaje filozofię Barucha Spinozy, która, według opinii autora, pełna jest takiego optymizmu. Spinoza namawiał bowiem do poddania się kierownictwu Rozumu, co oznaczać miało jednocześnie poddanie się wpływom dobra. Spinoza z tego też powodu nie uznawał żalu za grzechy; rozum i umiłowanie prawdy prowadzą lepszą drogą ku dobru, niż zgryzota i skrucha (amor Dei intellectualis).

27 W. James, Odmiany doświadczenia religijnego..., wyd. cyt., s. 88. Rzeczywistość realna jak gdyby traci swą moc znaczenia, mimo wszystko jednak zdrowomyślność jako postawa religijna nie jest sprzeczna z dążeniami natury ludzkiej. Jak zauważa James wszyscy, w mniejszym lub większym stopniu, odwracamy uwagę od chorób, śmierci czy w ogóle cierpienia. Dzięki temu bowiem świat jest ładniejszy i lepszy, niż ten, w którym rzeczywiście jesteśmy osadzeni jako niedoskonałe istoty rodzaju ludzkiego. Ujmując to językiem współczesnym, chociaż może trochę na wyrost, zdrowomyślność dziś jest podstawą tzw. propagandy sukcesu i wiecznej młodości. Między innymi hasło: „myśl pozytywnie, a twoje życie będzie szczęśliwe”, jest tym właśnie, co James określił jako zdrowomyślność. Już nawet niektórzy kaznodzieje nie wzmagają poczucia grzechu, lecz skupiają się na podkreślaniu wartości ludzkiej natury.

28 „Słyszymy wokół o Ewangelii Odprężenia, o ruchu Nie Trap Się, o ludziach, którzy ubierając się rano, powtarzają sobie jako motto na cały dzień «młodość, zdrowie, siła!». W wielu rodzinach nie wolno uskarżać się na brzydką pogodę i coraz bardziej przyjmuje się zwyczaj, że czymś nieprzystojnym jest mówienie o wrażeniach niemiłych lub zbytnie przejmowanie się powszednimi brakami i niedogodnościami". W. James, Odmiany doświadczenia religijnego..., wyd. cyt., s. 94. Innymi słowy, jest to forma optymizmu do obrzydzenia. 
doświadczenia wynika coś innego. Mianowicie to, że świat możemy, a nawet powinniśmy (w ramach tak zwanego humanizmu ${ }^{29}$ ) postrzegać i oceniać poprzez wiele systemów pojęć. Wybierającym system byłby człowiek, kierujący się własnymi, najbardziej subiektywnymi potrzebami ${ }^{30}$.

$\mathrm{Na}$ antypodach zdrowomyślności czy ducholecznictwa znajduje się stanowisko będące sposobem wynajdywania zła w świecie, które James określił jako „religię chorej duszy". Charakteryzuje ją przeświadczenie, że życie to przede wszystkim trwanie w grzechu, a sens świata najbliżej przejawia się w jego mrocznych aspektach. Innymi słowy, zło jest zasadniczą częścią istoty naszego życia i rzeczywistości ${ }^{31}$. Religię chorej duszy żywi człowiek „podwójnie urodzony” o chorobliwe wrażliwym sumieniu i rozszczepionej jaźni ${ }^{32}$; człowiek taki ma niezupełnie zjednoczony ustrój moralny i umysłowy ${ }^{33}$. Skupiony jest na najgorszych namiętnościach ludzkich. Podwójnie urodzony, ponieważ jednostka taka jest przeświadczona, że jeżeli urodzi się powtórnie (np. poprzez nawrócenie albo w inny, bardziej dosłowny sposób, reinkarnacyjny), wówczas zwycięży i dopiero wtedy odnaj-

29 Humanizm Jamesa oparty jest na jego pragmatycznej teorii prawdy, w której podkreśla element „ludzki”. Nie jest to jednak podkreślenie czystego subiektywizmu, ponieważ danego przekonania nie można uznać za prawdziwe, jeżeli nie uwzględnia i nie pozostaje się w relacji z wcześniejszymi przekonaniami. Prawda jest uzależniona od zmiennego doświadczenia i nie ma absolutnego wzorca prawdy na zewnątrz, a jedynie w działaniu. Por. F. Copleston, Historia filozofi, t. VII, przeł. Bohdan Chwedeńczuk, Warszawa 1995, s. 347-349.

30 Według Jamesa świat złożony jest z wielu przenikających się dziedzin rzeczywistości. Z tej też przyczyny możemy go rozpatrywać zarówno z perspektywy naukowej, jak i religijnej, poprzez użycie różnych pojęć i przyjmowanie różnych podstaw. Zob. W. James, Odmiany doświadczenia religijnego..., wyd. cyt., s. 117-118.

31 Tamże, s. 127.

32 Proces usuwania wewnętrznego rozszczepienia to nawrócenie, które może zajść przy dowolnym materiale umysłowym, niekoniecznie religijnym. Odrodzić można się nie tylko do religii, ale, jak zaznacza James, także do niewiary; nawracając się można odwrócić się od wrażliwości sumienia i skierować ku wolności lub rozwiązłości. „Odrodzenie bywa także - pisze James - powodowane wtargnięciem w życie danej osoby nowych pobudek i namiętności, takich jak miłość, ambicja, chciwość, mściwość lub patriotyzm. We wszystkich tych wypadkach zjawisko ma tę samą formę psychiczną: stałość, stabilność i równowagę przychodzące po okresie burzy, napięć i nieładu. W tych niereligijnych wypadkach nowy człowiek również może rodzić się stopniowo lub nagle". W. James, Odmiany doświadczenia religijnego..., wyd. cyt., s. 165-166. Istotą procesu nawrócenia jest przesunięcie się podniet w umysłowości ludzkiej. Dążenia wcześniej peryferyjne, znajdujące się na obrzeżach (marginesie) pola świadomości, przesuwają się pod wpływem danych bodźców ku środkowi, ku centrum pola świadomości. Zmienia się wówczas ośrodek energii, co w języku Jamesa oznacza zespół motywów, przyczyn dla których jednostka podejmuje działanie, źródło takiego a nie innego sposobu oglądania, interpretowania, odczuwania rzeczywistości i innych ludzi. Nadal jednak pozostają pod osnową tajemnicy siły, które uczestniczą w tym procesie, czyli to, w jaki dokładnie sposób dochodzi do tak radykalnej zmiany czyjegoś ośrodka energii.

33 W bardzo interesujący, lecz naiwny sposób, jak podaje James, próbowano wytłumaczyć taką właśnie niejednorodną osobowość. Otóż przyczyną wewnętrznego rozszczepienia miała być dziedziczność, a dokładnie niezgodne charaktery przodków. Zob. W. James, Odmiany doświadczenia religijnego..., wyd. cyt., s. 157-162. 
dzie spokój i szczęście ${ }^{34}$. Zdaniem Jamesa religia chorej duszy obejmuje większą skalę doświadczenia. Odwracanie uwagi od zła, zwyczaj życia z dnia na dzień, jest słuszne i dobre dopóki skutecznie działa. Załamuje się jednak przy pojawieniu się melancholii albo innego wypadku losowego. James natomiast w swoich badaniach przyjmuje hipotezę, ze złe fakty (zjawiska) są tak samo prawdziwymi składnikami świata, jak i te dobre. Świat odmawiający miejsca smutkowi, cierpieniu, śmierci jest niepełny i na swój sposób fałszywy, jest poetycką fikcją, a nie rzeczywistością ${ }^{35}$. Pierwiastki pesymistyczne są tak samo ważne, jak optymistyczne. James przecież zakłada wieloaspektowość świata, a nie jego jednorodność.

Wyżej opisane religijne cierpienia i stany szczęśliwości, które wchodzą w zakres doświadczenia religijnego są ważne ze względu na swoją różnorodność i tak zwane praktyczne owoce życiowe, które stanowią o wartości i znaczeniu uczuć religijnych. Za kryterium prawdy służy Jamesowi użyteczność - prawdziwa jest każda religia, która spełnia potrzeby życiowe człowieka ${ }^{36}$. Najwyższe i najgłębsze akty miłosierdzia, pobożności, prawdomówności, zaufania, świątobliwości, cierpliwości i męstwa, do których był zdolny człowiek, następowały, jak podkreśla James, przede wszystkim w wyniku oddziaływania ideałów religijnych ${ }^{37}$. Zjawisko nawrócenia jest wybitnym przykładem mocy, jaką może wyzwolić wiara w człowieku. Nasze naturalne skłonności lub zahamowania mogą radykalnie i nagle zniknąć z chwilą, gdy zjawi się silny bodziec wzruszeniowy. Jednak kwestią otwartą nadal pozostaje prawdziwość treści religii. Z badań Jamesa wiemy, że doświadczenie religijne równie dobrze może być wynikiem sugestii autorytetu albo naśladownictwa ${ }^{38}$. Równie dobrze mogą pojawić się fałszywe doświadczenia religijne. Jak zatem odróżnić prawdziwe stany duchowości od omamów?

Centralnym zagadnieniem badań nad doświadczeniem religijnym jest doświadczenie mistyczne, będące ośrodkiem duchowych stanów świadomości. Ja-

34 „Raz urodzeni” to zwolennicy religii zdrowomyślnej, niezdolni do odczuwania zła, przez co postrzegani są na drodze życia chorobliwego jako coś krańcowo zaślepionego i płytkiego.

35 Zob. W. James, Odmiany doświadczenia religijnego..., wyd. cyt., s. 154-155.

$36 \mathrm{~W}$ historii filozofii nie jest to nowe spojrzenie na religię. Religia prawie zawsze miała stronę funkcjonalną. Jak chociażby u takich filozofów, jak Kant (religia wyznacza normy i granice oraz uprawomocnia postępowanie wedle ogólnej maksymy), Feuerbach (religia jako forma wiedzy człowieka o samym sobie), Marks (opium ludu), Camus (religia jako oparcie w samotności).

37 W tym miejscu, jak i w jeszcze kilku innych, należy podkreślić niekonsekwencje Jamesa, co do ograniczenia przedmiotu badań. Zaznaczył bowiem na początku swych rozważań, że zakres jego analizy będzie „ponadreligijny”, jednak wielokrotnie odwołuje się do rozumienia religii w sposób chrześcijański. Zupełne nieodwoływanie się do religii usystematyzowanej, w kontekście doświadczenia religijnego, jest oczywiście niemożliwe. Warto o tej niekonsekwencji jednak wspomnieć, wskazując chociażby na fakt, że doświadczenie religijne nie jest całkowicie wolne od przynależności do wyznania.

38 Zob. W. James, Odmiany doświadczenia religijnego..., wyd. cyt., s. 108-109. 
mes doświadczenie mistyczne traktuje jako uprzywilejowany rodzaj doświadczenia. Warto zaznaczyć, że rozdział o mistycyzmie jest bogato wypełniony materiałem badawczym (świadectwami mistyków), co jest wynikiem realizacji postulatu radykalnego empiryzmu ${ }^{39}$.

Analiza doświadczenia mistycznego jest dla Jamesa okazją do ustalenia prawdziwości doświadczenia religijnego w ogóle. Zatem aby się ustrzec przed wieloznacznością terminu mistyczny, wymienia cztery charakterystyczne cechy mistycyzmu: niewyrażalność, jakość poznawcza, krótkotrwałość i bierność. Niewyrażalność stanowi negatywny wyróżnik mistycznego stanu umysłu; podmiot nie jest w stanie dokładnie określić treści swego stanu, chociaż doskonale odczuwa ją w swej świadomości. Wynika z tego, że właściwości tego stanu trzeba doznać bezpośrednio. Nie można ich udzielić, ani przekazać drugiemu podmiotowi tak, jak się przekazuje chociażby informację o pogodzie. Źródłem trudności, obok intymności (niewidzialności) stanów mistycznych, jest także to, że nie dysponujemy neutralnym językiem, w którym potrafilibyśmy wyrażać fenomeny mentalne, a tym bardziej anomalnych zjawisk mentalnych, jak mistyczne właśnie ${ }^{40}$. Jakość poznawcza stanów mistycznych powoduje, że podmiotom doznającym wydaje się, iż są to jednocześnie stany poznania, głębszego wejrzenia w prawdy niedostępne dla intelektu dyskursywnego. Krótkotrwałość natomiast czyni stany mistyczne chwilowymi uniesieniami duchowymi, nie mającymi tendencji do długiego trwania; jednak po tym, jak stan mistyczny przeminie, jego jakość w sposób niedoskonały daje się odtworzyć w pamięci. I w końcu bierność, która powoduje, że wprowadzona w stan mistyczny świadomość, odczuwa jak gdyby zależność od wyższej mocy; mistyk odczuwa zawieszenie własnej woli ${ }^{41}$.

Początkiem doświadczenia mistycznego może być pogłębione poczucie zrozumienia pewnej maksymy, którą wcześniej się usłyszało, a następnie, pod wpływem chwili, zrozumiało się jej treść. Równie dobrze w stan mistyczny może wprawić modlitwa, medytacja, pojedyncze słowo, zapach, dźwięk, barwa, światło, obraz. Doznawane jest wówczas poczucie tajemniczości i metafizycznej dwoistości rzeczy. Oczywiście James nie pomija także patologicznych stanów mistycznych, wywołanych środkami odurzającymi. I jak podkreśla, alkohol faktycznie jest wielkim inspiratorem ludzkiej funkcji afirmatywnej: „Przenosi swego wyznawcę z zimnych

39 Tamże, s. 343. Jednak nie tylko ze względu na empiryzm Jamesa. Także z tego powodu, jak zaznacza James na początku swoich rozważań, że on sam nigdy nie doświadczył stanu mistycznego, więc ilość przywołanych świadectw jest też swego rodzaju rekompensatą i chęcią zwiększenia wiarygodności badań i analiz, mimo braku bezpośredniego kontaktu z duchowością w sensie mistycznym.

40 James czyni tylko niewielkie wtrącenia o zagadnieniu języka w kontekście doświadczeń religijnych. Problem jest jednak znacznie większy i bardzo interesujący.

41 Zob. W. James, Odmiany doświadczenia religijnego..., wyd. cyt., s. 344-345. 
peryferii rzeczy do ich promienistego jądra. Na chwilę jednoczy go z prawdą. Ludzie poszukują alkoholu nie tylko ze zwykłej perwersji. Ubogiemu i analfabecie zastępuje on koncert symfoniczny i literaturę. Jest częścią głębszej tajemnicy i tragedii życia, że zapachy i przebłyski tego, co bezpośrednio rozpoznajemy jako doskonałe, tylu ludziom jest dostępne tylko w ulotnych wczesnych fazach procesu, który jako całość jest tak upadlającą trucizną" ${ }^{42}$. Świadomość pijanego człowieka jest okruchem świadomości mistycznej, której nie obowiązuje realny czas i przestrzeń. Jednak istnieje zasadnicza różnica między autentycznymi stanami mistycznymi, a tymi sztucznie wywołanymi. O ile w obu przypadkach stan taki jest krótkotrwały, to ten wywołany środkami odurzajacymi nie pozostawia po sobie wyraźnego śladu i dzieje się poza świadomością. Prawdziwe uniesienie mistyczne pozostawia po sobie trwałą zmianę i zostaje zachowane w pamięci. Kiedy ustępuje działanie środka chemicznego, powraca dawne poczucie stosunku do świata, doświadczenie „mistyczne” blednie i okazuje się omamem podniecenia mózgowego ${ }^{43}$.

Prawdziwe doznanie mistyczności, jedności ze światem trwale zmienia postrzeganie przez jednostkę rzeczywistości. W stanach mistycznych odczuwana jest jedność z Absolutem, bez względu na to, jak ten Absolut jest interpretowany ${ }^{44}$. „Na tym polega wiekuista i triumfująca tradycja mistyczna - podkreśla James niemal niezależna od klimatu i wyznania" ${ }^{45}$. Innymi słowy, świadomość mistyczna jest panteistyczna, optymistyczna i antynaturalistyczna.

Dobrze rozwinięte stany mistyczne, pisze James, mają niepodlegającą dyskusji władzę nad nawiedzanymi jednostkami. Ludzie ci byli „tam” i wiedzą. Wszelkie próby racjonalnego wytłumaczenia mistykom, że to iluzje nie mają żadnej mocy. Nikt i nic już nie może zmienić po takim doświadczeniu umysłu mistyka. Dla tych, którzy nie doświadczyli tego samego uczucia, tego rodzaju wzniosłości duchowej, jest pod wieloma względami trudne do zrozumienia. Doświadczenia mistyczne dla mistyków są równie bezpośrednim postrzeganiem faktu, jak dla tych, którzy swoje przekonania opierają na zmysłach. Mimo iż w stanach mistycznych zmysły

\footnotetext{
42 Tamże, s. 350.

43 Tamże, s. 354.

44 W tym miejscu warto przywołać Leszka Kołakowskiego, który w tym samym duchu, co James, definiował przymiotnik „mistyczny”. Pisał bowiem, że „mistyczny” oznacza: „doświadczenie, które, wedle rozumienia doświadczającego, wprowadza go w bezpośredni kontakt z pozaludzką rzeczywistością duchową, przy czym niekoniecznie łączy się to z wiarą w obecność Boga". L. Kołakowski, Jeśli Boga nie ma..., przeł. T. Baszniak, M. Panufnik, Kraków 1988, s. 103. O ile zatem doświadczenie mistyczne może stanowić rdzeń religii, np. katolickiej, to doświadczenie to nie jest tego życia warunkiem koniecznym. Wynika z tego, że doświadczenie mistyczne przede wszystkim należy rozumieć jako doświadczenie czegoś Wiecznego i Nieskończonego, poza konkretną religijną symboliką.
}

45 W. James, Odmiany doświadczenia religijnego..., wyd. cyt., s. 379. 
ulegają zawieszeniu, to postrzeżenia jednostek doświadczających pod względem swej jakości poznawczej są absolutnie zmysłowe; jednostka staje jak gdyby twarzą w twarz wobec przedstawień rzeczy, które wydają się istnieć bezpośrednio.

Doświadczenie mistyczne nie ma mocy autorytetu. James podkreśla, że mistyczność ma moc oddziaływania na mistyka i tylko na niego. Nie ma sposobu, aby narzucić osobom z zewnątrz bezkrytyczne uznanie objawień z tych stanów. Jest to nie tylko spowodowane brakiem odpowiedniego języka ${ }^{46}$, w którym możliwe byłoby wyrażenie takich doświadczeń, ale przede wszystkim przez to, że jeśli stoimy na zewnątrz i nie odczuwamy tego samego, to nic nie przemawia za tym, aby przyjąć to za prawdę albo własne doświadczenie. Próba przekonania innych do prawdziwości doświadczenia Jedyni czy Absolutu mogłaby polegać wyłącznie na odwołaniu się do ilości takich doświadczeń, a więc jedynie na mocy sugestywnej, nie zaś logicznej. Jednak i tutaj, pisze James, pojawiają się trudności. Nie istnieje bowiem jedność doświadczenia mistycznego. Ono także podlega wewnętrznemu zróżnicowaniu: mistycyzm ascetyczny, hedonistyczny, monistyczny, dualistyczny. Istnieje także mistycyzm diaboliczny, będący wynikiem obłędu lub paranoi. Wygląda tak samo, jak religijny, z tą różnicą, że jest pesymistyczny. Zamiast pocieszenia, zachwytu czy wzniosłości, jednostka odczuwa rozpacz, przerażenie i poczucie obecności złych mocy. Jednak bez względu na rodzaj doświadczenia mistycznego, mechanizm psychologiczny jest zawsze ten sam. Wypływa z podświadomej lub pozaświadomej dziedziny i wpływa na tę świadomą część. Fakt ten, że coś pochodzi z obszaru podświadomego, nie zapewnia wiarygodności tych doświadczeń. Zatem, stwierdza James, jeżeli sami nie jesteśmy mistykami, wartość tych stanów należy ustalić metodą empiryczną ${ }^{47}$, chociaż i tak nie gwarantuje to wejścia w posiadanie wiedzy pewnej.

Stany mistyczne informują nas, że świadomość racjonalistyczna jest tylko pewnym rodzajem świadomości, że istnieje coś więcej. Konsekwencją natomiast takiego myślenia jest teza, że świat widzialny jest tylko cząstką wszechświata bardziej duchowego ${ }^{48}$. Kolejnym wnioskiem, o którym pisze James, jest istnienie możliwości połączenia naszego celu z tym wyższym poziomem wszechświata. Innymi słowy, każdy na swój własny sposób powinien odnaleźć to, czym jest ten duch i wejść z nim w harmonijną relację. Natomiast samo doświadczenie religijne,

\footnotetext{
46 W tym miejscu warto przywołać niezwykle ciekawą interpretację Manfreda Geiera, przedstawiającą Ludwiga Wittgensteina jako mistyka. Oczywiście nie w sensie określonej dogmatyki czy jakiegoś spirytualizmu, lecz przez jego filozofię języka, i podejmowane próby odnalezienia sposobu dokładnego wyrażenia tego, co jednostka myśli czy odczuwa. Por. M. Geier, Gra językowa filozofów. Od Parmenidesa do Wittgensteina, przeł. Janusz Sidorek, Warszawa 2000.

47 Zob. W. James, Odmiany doświadczenia religijnego..., wyd. cyt., s. 382-385.

48 Por. P. Boyer, I człowiek stworzył Bogów..., przeł. Krystyna Szeżyńska-Maćkowiak, Warszawa 2005.
} 
jak wykazują badania Jamesa, wyraźnie wpływa na jednostkę, dokonując zmian $\mathrm{w}$ jej życiu ${ }^{49}$. A skoro realnie ingeruje w egzystencje jednostki, to samo również musi mieć coś z rzeczywistego istnienia. Doświadczenie jest nie tylko zewnętrzną percepcją świata, ale uczestniczeniem w świecie. Jest życiem i działaniem indywidualnym. Kwestia użyteczności stanów duchowych, czyli fakt, że są źródłem miłosierdzia, świątobliwości, nawrócenia, altruizmu, ascetyzmu, jest tym właśnie, co nie pozwala na całkowite odrzucenie doświadczenia religijnego lub określenie go mianem omamu czy iluzji ${ }^{50}$.

Postulat radykalnego empiryzmu, którego zwolennikiem był James, głosi, że nic nie jest uzasadnione, co nie opiera się bezpośrednio lub pośrednio na doświadczeniu. Doświadczenie jest jedynym i pewnym źródłem oraz kryterium prawomocności wiedzy. Wszystko, co realne, musi być wykazane w doświadczeniu. Jednak w rozumieniu Jamesa, jak już zostało wyżej pokazane, doświadczenie nie jest jedynie zmysłową rejestracją bodźców. Doświadczenie nie jest złożone z różnych elementów danych zmysłowych, lecz jest ciągłe, jest strumieniem przeżyć, związanych z jednostkową jaźnią ${ }^{51}$. Nie ma jakiejś wyraźnej różnicy między tym, w jaki sposób James ujmował świadomość, a w jaki doświadczenie. Traktował je głównie jako zjawiska pokrewne, a nawet tożsame. Świadomość zatem nie jest czymś oderwanym od podmiotu; jest strumieniem przeżyć, związanym z indywidualnym podmiotem. Świadomość nie tylko łączy i uogólnia dane, ale także odrzuca lub wybiera dane. James podkreślał jej aktywny i twórczy charakter ${ }^{52}$.

49 W. James, Odmiany doświadczenia religijnego..., wyd. cyt., s. 437.

50 Richard Rorty analizując pojęcie prawdy posługiwał się kategoriami solidarności i obiektywności. Zwolennicy obiektywności, inaczej realiści, to ci, którzy prawdę pojmują w sposób klasyczny jako zgodność z rzeczywistością; opisują rzeczywistość bez odnoszenia się do istot ludzkich, prawdę traktują jako idee. Zwolennicy solidarności natomiast to ci, którzy skupieni są wokół życia wspólnoty, prawdę traktują jako dobro indywidualne, wspólne, użyteczne. Jamesa i pragmatystów oczywiście określił Rorty jako zwolenników solidarności. Z jednej strony jest to oczywiste, wynika to jasno z założeń pragmatyzmu. Uzasadnienie prawdziwości danego doświadczenia, zjawiska, przekonania nie jest dla pragmatystów sprawą najważniejszą. Uzasadnienie użyteczności natomiast tak. Rzeczywistość rozpatrywana jest w układzie nieużyteczny-zły-fałszywy, użyteczny-dobry-prawdziwy. Z drugiej zaś, o ile James nie pomijał użytkowego aspektu religii, to w swych badaniach dotyczących doświadczenia religijnego poszukiwał istoty, osobliwości tego doświadczenia. Szukał zatem czegoś, co można określić jako prawdę o doświadczeniu religijnym. James nie odwoływał się wyłącznie do użyteczności, w ramach określenia istoty tego doświadczenia. Użyteczność uważał za jego przejaw. Istotą natomiast była niewyrażalność, krótkotrwałość, bierność, subiektywna jakość poznawcza. Prawdziwe stany duchowe mogą być również użyteczne jak omamy. W poszukiwanej osobliwości zatem chodziło o obiektywność, o niesprowadzalność tego doświadczenia do żadnego innego, o takie cechy, które występują zawsze i u wszystkich doświadczających boskiej tajemnicy. Zob. R. Rorty, Obiektywność, relatywizm i prawda, przeł. Janusz Margański, Warszawa 1999, s. 35-54. Por. W. James, Pragmatyzm, przeł. M. Filipczuk, Kraków 2004, s. 118-130.

51 Zob. A. J. Ayer, Filozofia w XX wieku, przeł. Tadeusz Baszniak, s. 90-108.

52 Zob. B. Krawcowicz, William James. Pragmatyzm i religia, Wrocław 2007, s. 43-45. 
W świetle tych założeń doświadczenie jest czymś więcej niż zmysłowym postrzeganiem świata; doświadczenie odnosi się do bezpośredniego ujmowania rzeczywistości i obejmuje doznania, emocje oraz niejasne „odczucia powiązań”. Dlatego też doświadczenie religijne jest realne poprzez subiektywną użyteczność. Bóg nie jest poznawany ani rozumiany, lecz używany ${ }^{53}$. Może przejawiać się jako wsparcie moralne, jako przyjaciel lub przedmiot miłości, jednak najważniejsze jest to, czy jest użyteczny. Analiza Jamesa pokazuje, że celem religii czy doświadczenia religijnego nie jest udowodnienie istnienia Boga, lecz wzbogacenie i afirmacja życia. Doświadczenie religijne jest w tym sensie rzeczywiste, że wywołuje zmiany w rzeczywistości. Jednak nie stanowi ono samo w sobie dowodu potwierdzającego przekonanie o nieśmiertelności duszy czy nieskończoności Boga. Jedyną rzeczą, pisze James, jaką doświadczenie religijne jest w stanie potwierdzić, jest fakt, że w uniesieniu duchowym doświadczamy związku z „czymś” większym od nas, w czym znajdujemy ukojenie.

Doświadczenie religijne jest odmienne od doświadczenia czysto zmysłowego. Jednak w opinii Jamesa jest równie prawomocne w odczuwaniu rzeczywistości. Z tą tylko różnicą, że duchową, a nie realno-zmysłową. Nie usuwa to niemniej wątpliwości, czy użyteczność takiego duchowego wymiaru wszechświata wystarczy, aby ze spokojem umysłu przyjąć jego realne oddziaływanie i doświadczanie.

\section{Summary}

The aim of this paper is the presentation of W. James' concept of religious experience. The main problem is whether a religious experience has the same certainty as a sensual one and what it refers to, i.e. what its object is: a fictitious realm of being or a kind of other reality - unknown for an ordinary experience. Another problem consists in whether the qualities of religious experience (as James says) such as unexaminability and incommunicatibility can be a philosophical issue or rather the object of psychiatry.

53 Interesującym kontrapunktem w kwestii pragmatyczności religii jest książka Michela Onfraya Traktat ateologiczny, w której analizuje użyteczność religii, jednak w całkowicie innym sensie, niż zrobił to James. Zob. M. Onfray, Traktat ateologiczny, przeł. Matusz Kwaterko, Warszawa 2009. 


\section{Bibliografia}

Blackburn, Simon, Oksfordzki stownik filozoficzny, przeł. Jan Woleński, Cezary Cieśliński, Paweł Dziliński, Michał Szczubiałka, red. naukowy Jan Woleński, Warszawa 2004.

Boyer, Pascal, I człowiek stworzył Bogów..., przeł. Krystyna Szeżyńska-Maćkowiak, Warszawa 2005.

Ayer, A. J., Filozofia w XX wieku, przeł. Tadeusz Baszniak, Warszawa 2003.

Copleston, Frederick, Historia filozofii, t. VII, przeł. Bohdan Chwedeńczuk, Warszawa 1995.

Copleston, Frederick, Historia filozofi, t. IX, przeł. Bohdan Chwedeńczuk, Warszawa 1991.

Geier, Manfred, Gra językowa filozofów. Od Parmenidesa do Wittgensteina, przeł. Janusz Sidorek, Warszawa 2000.

James, William, Odmiany doświadczenia religijnego. Studium ludzkiej natury, przeł. Jan Hempel, Warszawa 2011.

W. James, Pragmatyzm, przeł. M. Filipczuk, Kraków 2004.

W. James, Z wybranych problemów filozofii, przeł. M. Filipczuk, Kraków 2004.

Kołakowski, Leszek, Jeśli Boga nie ma..., przeł. T. Baszniak, M. Panufnik, Kraków 1988.

Krawcowicz, Barbara, William James. Pragmatyzm i religia, Wrocław 2007.

Leeuw van der, Gerardus, Fenomenologia religii, przeł. Jerzy Prokopiuk, Warszawa 1997.

Onfray, Michel, Traktat ateologiczny, przeł. Matusz Kwaterko, Warszawa 2009.

Otto, Rudolf, Świętość. Elementy irracjonalne w pojęciu bóstwa i ich stosunek do elementów racjonalnych, przeł. Bogdan Kupis, Thesaurus Press 1993.

Rorty, Richard, Obiektywność, relatywizm i prawda, przeł. Janusz Margański, Warszawa 1999.

Skarga, Barbara, Kwintet Metafizyczny, Kraków 2005.

Autorka jest doktorantką w Instytucie Filozofii UW 